\title{
MARKETING OF GREEN PRODUCTS- CUSTOMER PERSPECTIVE
}

\section{Dr. M. Renuka Devi*}

Associate Professor, Department of Corporate Secretaryship, PSG College of Arts \& Science, Coimbatore. *Corresponding Author

Assistant Professor, Department of Corporate Secretaryship, PSG College of Arts \& Science, Coimbatore.

ABSTRACT A green product as one that has less of an environmental impact or is less detrimental to human health that the traditional product equivalent. Now-a-days, peoples are becoming more conscious about health and environment. Green products will be produced by using organic fertilizers, without using any pesticides, insecticides, any inorganic fertilizers, or toxic elements. So, the demand for such products has doubled when compared to the last ten years. The changing climatic condition is not just a talk but has become an international concern. This awareness is greatly affecting consumer's purchasing decision. Even marketers are taking measures to minimize the production of harmful wastes. In the present scenario, brands producing green products use green marketing to communicate their value proposition to the market. Green products will be healthier in nature and safe to use.In this present study, to make a research on green products marketing among the consumers and their perspective.

\section{KEYWORDS :}

\section{INTRODUCTION:}

The term "green" or "sustainable" often refer to products, services or practices that allow for economic development, while conserving for future generations. Green products are the products that contain recycled materials, waste, conserve energy or water, use less packing, and reduce the amount of toxics disposed or consumed. In the past 50 years, humans have consumed more resources than in all previous history, this and other eco facts like breathing of polluted air, using of plastic bags etc. It has drawn great attention of the end consumer towards green products and their benefits called green generation, these consumers are more inclined to "going green". They believe in making decisions that are environmentally friendly and use products that are sustainable and cause very less or no pollution.

Green products are usually identified by having two basic goals (i.e.) reducing waste and maximizing resource efficiency. They are manufactured using toxic- free ingredients and environmentally- friendly procedures and are certified by recognized organizations like Energy Star, Forest Stewardship Council, etc. Since eco-friendly products are made from materials that are free from harmful chemicals and components, they not only improve physical but also mental health. Green products concentrates all the products like food products, cosmetics, eco-friendly dishwashers, etc. even constructing of buildings also. For instance, In green buildings large windows are installed which allows healthy and fresh air along with natural lighting in abundance. It improves mental health and reduces stress. Green products are costly products having heavy investment, but it is healthier to the humans and eco-friendly one.

\section{OBJECTIVES:}

1. To study the factors that influences to purchase of green products.

2. To study the customers satisfaction towards using of green products.

3. To study the problems faced by the customer in using of green products.

\section{Statement Of The Problem:}

Day- to-day life consumers use variety of products and services to their satisfaction. In recent years, there is a lot of discussion about the impact of the products that they use and a research the consumers are able to know as to how it affects their health. In viewing the above, the customers started to looking for alternative products which do not create any side effects. In this context, peoples started moving to green products slowly. So, here is an attempt to make a study the customer perception towards marketing of green products.

\section{REVIEW OF LITERATURE:}

Serban.C.(2015) 1 , made a study on "Consumer Perception Analysis - Market Awareness Towards Eco-Friendly Fmcg Products - A Case Study Of Mysore District" concludes that there is a strong relationship between consumers willingness to adopt a responsible ecological behavior and social organizations who initiated campaigns to address the issue.

Dubey and Gupta (2016) ${ }^{2}$, and took a study on "Role Of Green Marketing In India" said that Indian market costumers too are prepared to pay premium cost for green items and at last green marketing necessitates that customers need a cleaner domain and will pay for it , perhaps through higher estimated products, changes individual ways of life, or even administrative meditation.

P.Asha(2017) ${ }^{3}$, made a study on "Consumer Awareness Towards Green Products", concluded that the awareness drives regarding availability and green product are required to popularize the product of the accept to promote the green products segment is senior and middle aged citizens.

Banu Praveen M.A. et.al(2019) ${ }^{4}$, made a study on "A Study On Awareness Of Green Marketing In Tiruchirappalli District", green marketing is a concept of terminology which is being used preserve or protect our environment. The main objective of a study is to ascertain the features of the green product to user suggestion to improve green product. The researcher used statistical tools for the study is simple percentage analysis and chi square analysis. The study reveals that to improve green product quality should be better than standard products and the study concludes that green marketing or green products are protecting the environment as well as educating the society how to protect the environment. "SWACHH BHARAT" also made a significant impact in the mind set of the people of the green products and marketing companies are educating the people about the environment.

\section{RESEARCH METHODOLOGY:}

Area of the Study: The area of the study refers to Coimbatore city. 
Sample Size: For the purpose of the study 200 respondents were taken.

Sources of Data: For the purpose of the study both primary and secondary data were used .The primary data is collected by scheduled questionnaire. The secondary data is collected by using various journals, articles and websites.

Sampling Technique: For the purpose of the study Random sampling technique has been adopted.

Tools for analysis: Simple percentage analysis, Weighted average rank score, Diagrammatic representation has been used for the study.

\section{ANALYSIS AND INTERPRETATION:}

Table 1 Demographic Analysis

\begin{tabular}{|c|c|c|c|}
\hline \multicolumn{2}{|c|}{ Demographic factors } & \begin{tabular}{|l|} 
Total \\
no. of \\
respon \\
dents
\end{tabular} & $\begin{array}{l}\text { Percenta } \\
\text { ge }\end{array}$ \\
\hline \multirow[t]{2}{*}{ Gender } & Male & 88 & $44 \%$ \\
\hline & Female & 112 & $56 \%$ \\
\hline \multirow[t]{4}{*}{ Age } & Less than 30 years & 32 & $16 \%$ \\
\hline & $31-40$ years & 40 & $20 \%$ \\
\hline & $41-50$ years & 48 & $24 \%$ \\
\hline & Above 50 years & 80 & $40 \%$ \\
\hline \multirow{4}{*}{$\begin{array}{l}\text { Educational } \\
\text { qualification }\end{array}$} & No formal education & 8 & $4 \%$ \\
\hline & School level & 36 & $18 \%$ \\
\hline & College level & 72 & $36 \%$ \\
\hline & Professional qualification & 84 & $42 \%$ \\
\hline \multirow{4}{*}{$\begin{array}{l}\text { Occupational } \\
\text { Status }\end{array}$} & Agriculture & 48 & $24 \%$ \\
\hline & Business & 72 & $36 \%$ \\
\hline & Professionals & 48 & $24 \%$ \\
\hline & Others & 32 & $16 \%$ \\
\hline \multirow{2}{*}{$\begin{array}{l}\text { Marital } \\
\text { status }\end{array}$} & Married & 120 & $60 \%$ \\
\hline & Unmarried & 80 & $40 \%$ \\
\hline \multirow{2}{*}{$\begin{array}{l}\text { Nature of } \\
\text { family }\end{array}$} & Joint family & 60 & $30 \%$ \\
\hline & Nuclear family & 140 & $70 \%$ \\
\hline \multirow{4}{*}{$\begin{array}{l}\text { Family } \\
\text { monthly } \\
\text { income }\end{array}$} & Less than Rs. 10,000 & 32 & $16 \%$ \\
\hline & Rs. 10,000 to Rs. 20,000 & 48 & $24 \%$ \\
\hline & Rs.20,001 to Rs.30,000 & 56 & $28 \%$ \\
\hline & Rs.30,001 to above & 64 & $32 \%$ \\
\hline
\end{tabular}

Source: primary data

From the above table it is found that, majority (56\%) of the respondents are belongs to female,most $(40 \%)$ of the respondents belongs to the age group of above 50 years, most $(42 \%)$ of the respondents have completed professional qualification, most $(36 \%)$ of the respondents are belongs to professionals as their occupational status, most (40\%) of the respondents are belongs to unmarried as their marital status, most $(30 \%)$ are belongs to joint family, and most ( $16 \%)$ of the respondents are belongs toLess than Rs.10,000 as their family monthly income.

Table 2 Problems Faced By The Customers

\begin{tabular}{|l|l|l|}
\hline Nature of problem & Total no. of respondents & Percentage \\
\hline Side effects & 44 & $22 \%$ \\
\hline Lack of availability & 60 & $30 \%$ \\
\hline Health complications & 48 & $24 \%$ \\
\hline Others & 48 & $24 \%$ \\
\hline Total & 200 & $100 \%$ \\
\hline
\end{tabular}

Source: primary data

From the above table, it is inferred that out of total number of respondents were taken for the study, 48 (24\%) respondents have faced the nature of problems like health complications, and, other problems. 60 (30\%) respondents have faced lack of availability of the green products and $44(22 \%)$ respondents have faced side effects.

\section{Total no. of respondents}

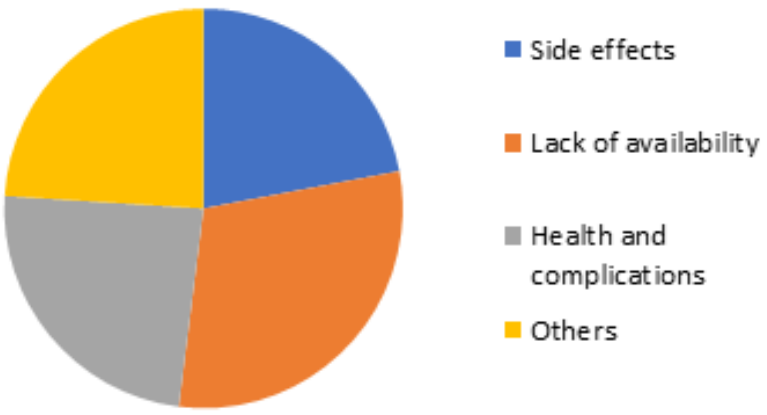

Table 3 Factors That Influence To Use Green Products

\begin{tabular}{|c|c|c|c|c|c|c|c|c|c|}
\hline \multirow[t]{2}{*}{ Factors } & & 6 & 5 & 4 & 3 & 2 & 1 & \multirow[t]{2}{*}{ Total } & \multirow[t]{2}{*}{ Rank } \\
\hline & & 1 & 2 & 3 & 4 & 5 & 6 & & \\
\hline \multirow[t]{2}{*}{ Health } & No & 44 & 48 & 32 & 32 & 32 & 12 & \multirow[t]{2}{*}{4.02} & \multirow[t]{2}{*}{$\mathrm{V}$} \\
\hline & Score & 264 & 240 & 128 & 96 & 64 & 12 & & \\
\hline \multirow[t]{2}{*}{ Quality } & No & 72 & 52 & 24 & 20 & 28 & 4 & \multirow[t]{2}{*}{5.54} & \multirow[t]{2}{*}{ I } \\
\hline & Score & 432 & 260 & 96 & 60 & 56 & 4 & & \\
\hline \multirow[t]{2}{*}{ Price } & No & 76 & 36 & 32 & 24 & 20 & 12 & \multirow[t]{2}{*}{2.54} & \multirow[t]{2}{*}{ VI } \\
\hline & Score & 456 & 180 & 128 & 72 & 40 & 12 & & \\
\hline \multirow{2}{*}{$\begin{array}{l}\text { Environmental } \\
\text { free }\end{array}$} & No & 68 & 65 & 32 & 24 & 16 & 2 & \multirow[t]{2}{*}{4.84} & \multirow[t]{2}{*}{ II } \\
\hline & Score & 408 & 325 & 128 & 72 & 32 & 2 & & \\
\hline \multirow[t]{2}{*}{ Taste } & No & 56 & 48 & 40 & 28 & 24 & 4 & \multirow[t]{2}{*}{4.36} & \multirow[t]{2}{*}{ IV } \\
\hline & Score & 336 & 240 & 160 & 84 & 48 & 4 & & \\
\hline \multirow[t]{2}{*}{ No side effects } & No & 72 & 40 & 32 & 24 & 20 & 12 & \multirow[t]{2}{*}{4.42} & \multirow[t]{2}{*}{ III } \\
\hline & Score & 432 & 200 & 128 & 72 & 40 & 12 & & \\
\hline
\end{tabular}

Source: primary data

From the above table, it is found that majority of the respondents have given up priority for the factors, which are followed by Quality, Environmental free, No side effects, Taste, Health, and, Price that influences them to use green products.

\section{FINDINGS, SUGGESTIONS AND CONCLUSIONS:}

\section{FINDINGS:}

1. Majority (56\%) of the respondents are belongs to female,most $(40 \%)$ of the respondents belongs to the age group of above 50 years, most (42\%) of the respondents have completed professional qualification, most (36\%) of the respondents are belongs to professionals as their occupational status, most $(40 \%)$ of the respondents are belongs to unmarried as their marital status, most (30\%) are belongs to joint family, and most (16\%) of the respondents are belongs toLess than Rs.10,000 as their family monthly income.

2. Most (24\%) respondents have faced the nature of problems like health and complications, and, other problems, most (30\%) respondents have faced lack of availability of the green products and, most $(22 \%)$ respondents have faced side effects.

3.Majority of the respondents have given up priority for the factors which are followed by Quality, Environmental free, No side effects, Taste, Health, and, Price that influences them to use green products.

\section{SUGGESTIONS:}

1. Manufacturers and Retailers to put adequate effort in creating awareness about green products among the consumers either through the media.

2. Quality and availability of green products to cover large part of consumers this will help the marketing to green product to become smooth and effective.

3. The changing life style of people and modernization of their living behavior, it is very important that the consumer must be well informed and educated towards using green products. 
CONCLUSION:

Green marketing should not be considered as just one more approach to marketing, but has to be pursued with much greater vigor, as it has an environmental and social dimension to it. Green marketing assumes even more importance and relevance in developing countries like India. It helps in the effective outcomes like cost cutting, employee satisfaction, waste minimization, society welfare for the companies as well for society also. Consumers want to identify themselves with companies that are green complaint and are willing to pay a premium for a greener life style. Green marketing is not just an environmental protection tool but also, a marketing strategy.

\section{REFERENCES:}

1. Serban.C.(2015) ${ }^{1}$, "Consumer Perception Analysis - Market Awareness Towards Eco-Friendly Fmcg Products - A Case Study Of Mysore District", IOSR Journal of Business and Management, pg.no:22-26.

2. Dubey and Gupta (2016) $)^{2}$,"Role Of Green Marketing In India" , Imperial Journal of Interdisciplinary Research, pg.no: 1137-1139.

3. P.Asha $(2017)^{3}$, "Consumer Awareness Towards Green Products" International Journal of Management pg.no: 8-14.

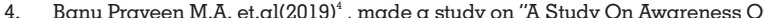
Green Marketing In Tiruchirappalli District", IJRAR Feb 2019, vol.6, issue no.l, pg.no: 271-277

5. www. forgreen.com

6. www.greenmarketing.net 